\section{Concept of the Creation of Eco- rural Tourism Destination on the Example of Gudurica Settlement}

\section{Romelić, Jovan, \\ Plavša, Jovan, \\ Stojanović, Vladimir'}

\begin{abstract}
The paper studies all the relevant conditions and factors, with the emphasis on the so-called basic resources which form natural and social tourist attraction of the rural settlement of Gudurica and its surroundings, and explores possibilities and strategies to turn this settlement into an eco-rural destination.
\end{abstract}

Key words: Eco-rural tourism, Gudurica, Serbia and Vojvodina

\section{Jovan Romelić, Jovan Plavša, Vladimir Stojanović}

Faculty of Natural Science, Department for Geography, Tourism and Hotel Management, Trg Dositeja Obradovića 3, 21000 Novi Sad, Serbia

\section{Introduction}

The paper results from the current position of eco-rural tourism in the world and favorable conditions for its development in Gudurica. It also renders the strategies of development of eco-tourism on potential resources and points to its specific features and significant role in demographic and economic recovery of the village.

The basic goals of the paper are based on inventory and qualitative approach to tourist valorisation of Gudurica as a potential eco-rural destination. These would be the following: 1) selection and evaluation of the usage value of natural conditions in the village surrounding, 2) evaluation of the values of cultural-historical heritage from the point of usability for the needs of establishment and development of eco-rural tourism, 3) the development of receptive eco-tourism basis, 4) conservation and reconstruction of objects that mark tradition continuity and development, 5) establishment of eco-rural tourism in private agricultural households, public objects with well-preserved rustic elements, as well as in residential objects that were built according to standard, modern concepts (secondary importance), 6) concept of heterogeneous and dynamic tourist offer and 7) maximal usability of complementary values in the surrounding area. Joining of eco-rural tourism with economic activities and branches, groups and subgroups of activities that with their authenticity and tradition form an integral part of tourism in general.

\section{Basic notion of eco-rural destination}

Working definition of eco-rural destination which will serve as the basis of relevant indicators and sub indicators for the explanation of such destination, is reached by combining definitions of the following terms: destination (Encyclopedia of Tourism, 2001), eco tourism (IUCN, 1996), and rural tourism (Popesku, 2002).

Eco-rural destination is a larger area functioning as a unit, which builds its tourist identity on the concept of cumulated attractions, which combine the experience they offer and appropriate infrastructure,

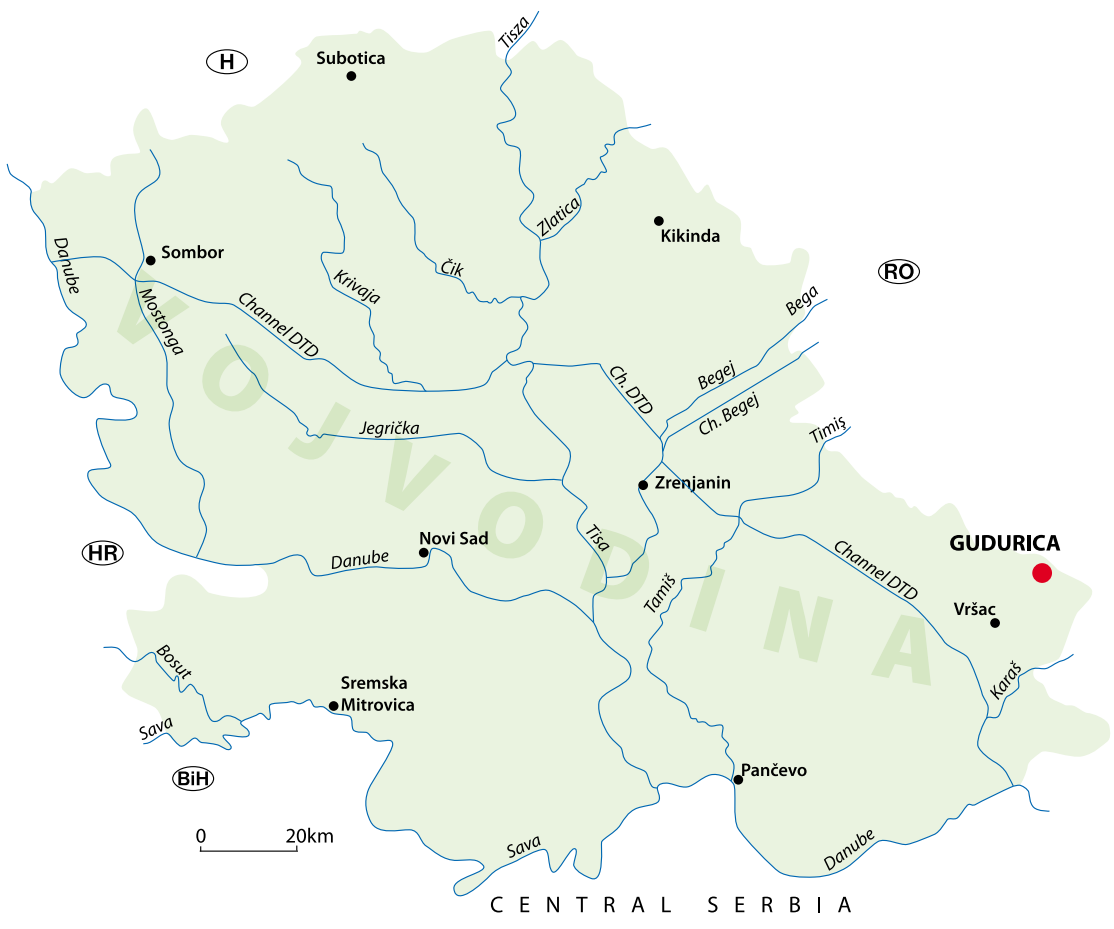

Figure 1 Geographical position of Gudurica 


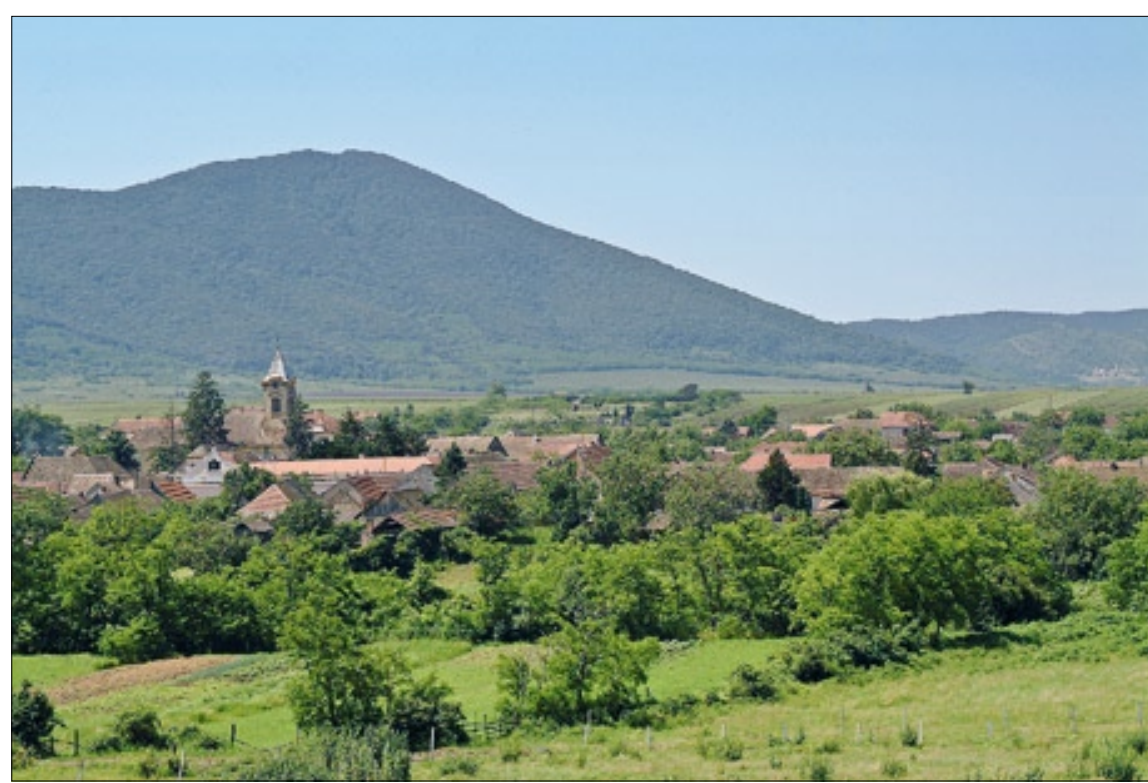

Figure 2 Panorama of Gudurica, beneath Gudurički vrh

and represent the area of intensive tourist gathering. Such destination, an undisturbed region of nature, receives visitors who get pleasure from the nature and respect the nature and cultural objects of the present and past. It also promotes preservation of the nature by receiving little influence of visitors and thus provides useful and active social and economic engagement. Prospective tourists, who come mainly from urban regions, define the rural character of the destination primarily according to the level of traditional social structures as well as general social values which are not present in urban centres. First of all, rural areas are supported by strong feeling of coexistence, local instead of cosmopolitan way of life, which is "slower", less materialistic and less complicated in comparison to urban areas. Modern tourists' growing interest in cultural heritage emphasizes the relevance of the features of the rural areas.

According to this, eco-rural tourist destination comprises higher concentration of preserved attractive resources in the area which enable functional orientation in tourism. It is visited by the tourists who respect the nature and rural environment, which differs from the urban one by its simplicity in the way of life, thus being more attractive to urban stressed-out people.

\section{Gudurica - review of basic natural conditions for eco-rural tourism development}

Gudurica is situated in Vojvodina, southern Banat (Figure 1), occupying traditional agricultural area. It is one of the most important villages in the municipality of $\mathrm{Vr}$ sac. It had the largest population $(2,812)$ in 1890 , and it is still among bigger villages in the municipality with the population of $(1,267)$ in 2002. development se the special attention must be paid on Gudurica, whose potentials will be analyzed in more details.

The fact that Gudurica (as well as Malo Srediste, Veliko Srediste, and Markovac) is built in the north foot of the $\mathrm{Vr}$ sacke Mountains, i.e. on the contact point of piedmont and abrasive terrace, renders certain physiognomic and functional specific features. Besides, through the middle part of Gudurica area, from the southeast to northwest, there is the valley of Markovacki stream, which regardless its spatial restrictions offers special landscape and ambience value (Bukurov, 1950)

The analysis of the position of Gudurica and other settlements in the area may raise the question of justification of tourism development, because this area is far from regional road lines, sometimes called "appendices of Banat". However, eco and rural tourism does not demand modern and busy traffic lines. It is sufficient that there is a solid asphalt road to reach an eco-rural destination. Otherwise, it would be considered too urban and unattractive for prospective tourists coming from the urban areas. Moreover, from Vrsac -municipality centre, all the way to Gudurica there is an asphalt road. It also goes through Veliko Srediste and ends in three kilometers away Markovac. Malo Srediste is also about three kilometers further. Therefore, it can be said that Gudurica is on the halfway between these settlements and it must preserve that position in eco-rural tourism development.

Observed morphologically, the basic plan of the settlement Gudurica is of irreg ular shape. The village stretches along the left side of the Markovacki brook valley. The main street follows the edge of the valley side, and the village broadens towards south near the abrasive area. The map of the streets is also irregular, net type, which is

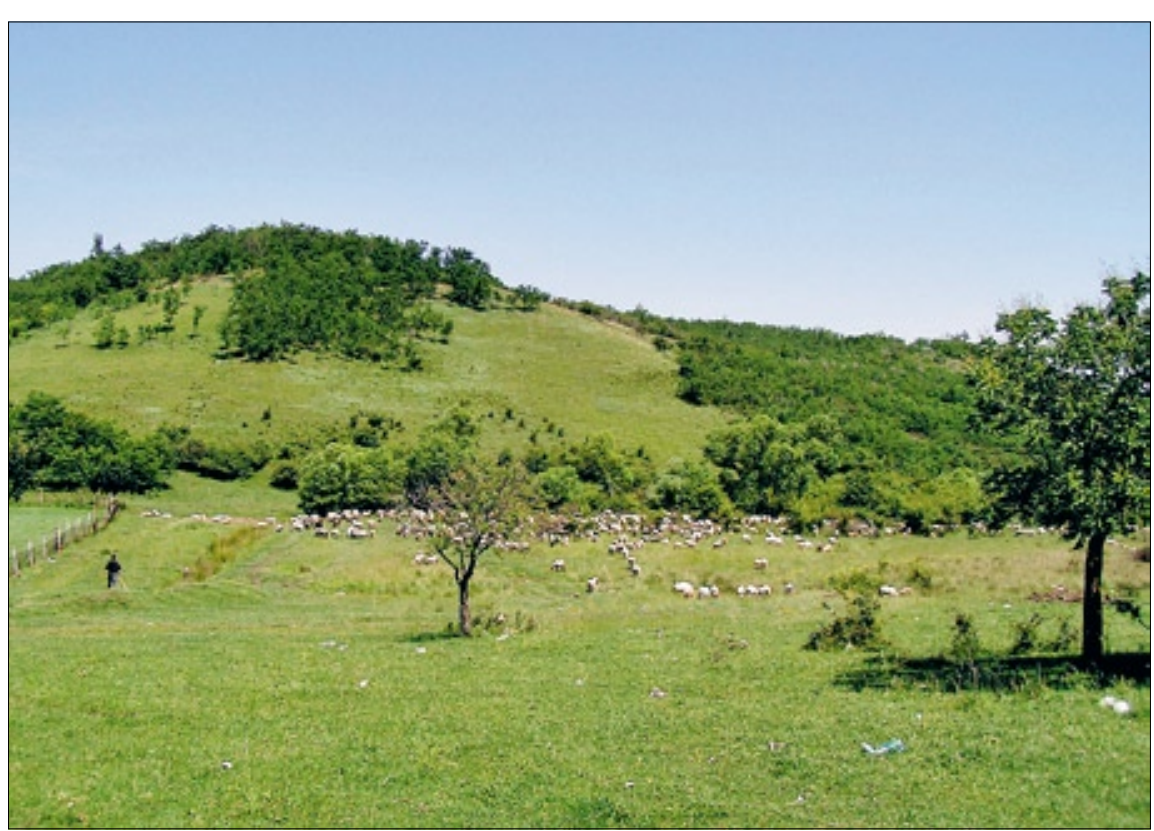

Figure 3 Cattle-breeding as part of rural tourism offer 
typical for mountainous villages. It is one of the factors which make the village a specific one in the area of Vojvodina. Streets are not of the same width, and crossroads are widened on few places. One of these places is in the village centre, and right next to it are church and school. For visitors who come to this place for the first time, central ambient atmosphere has preserved the signs of once well-designed and organized area with elements of mountainous village.

In the central part of the village there is a possibility of conservation, reconstruction and making a network of comfortable but rustic accommodation and catering objects, which would also offer cultural, entertainment and recreational facilities (Figure 4). The restaurants with local cuisine should be owned by the local population. The households for the reception of tourists should work in concordance to the law, and financially sustainable. Other houses used for accommodation of tourists should portrait the local character and traditional style.

The accommodation objects which comply with the standards of the eco-rural destination should be organized according to the predictable stable base of the visitors. That is to say, architectural solutions should not disturb general orientation towards tradition, authentic ambience, the meals, bathroom facilities, etc.

As a centre of all future happenings and the creation of specific visual village identity, it is necessary to prepare few public objects. The best for that purpose are: building of old wine cellars, public offices, hunting house, old citizens' center, culture center, Catholic church, etc.

These objects would be in the function of public presentations, exhibitions, lectures, workshops, cultural-entertainment manifestations.

Gudurica was the most important vineyard centre in the villages of the Vrsacke Mountains, by the WWII and even later.

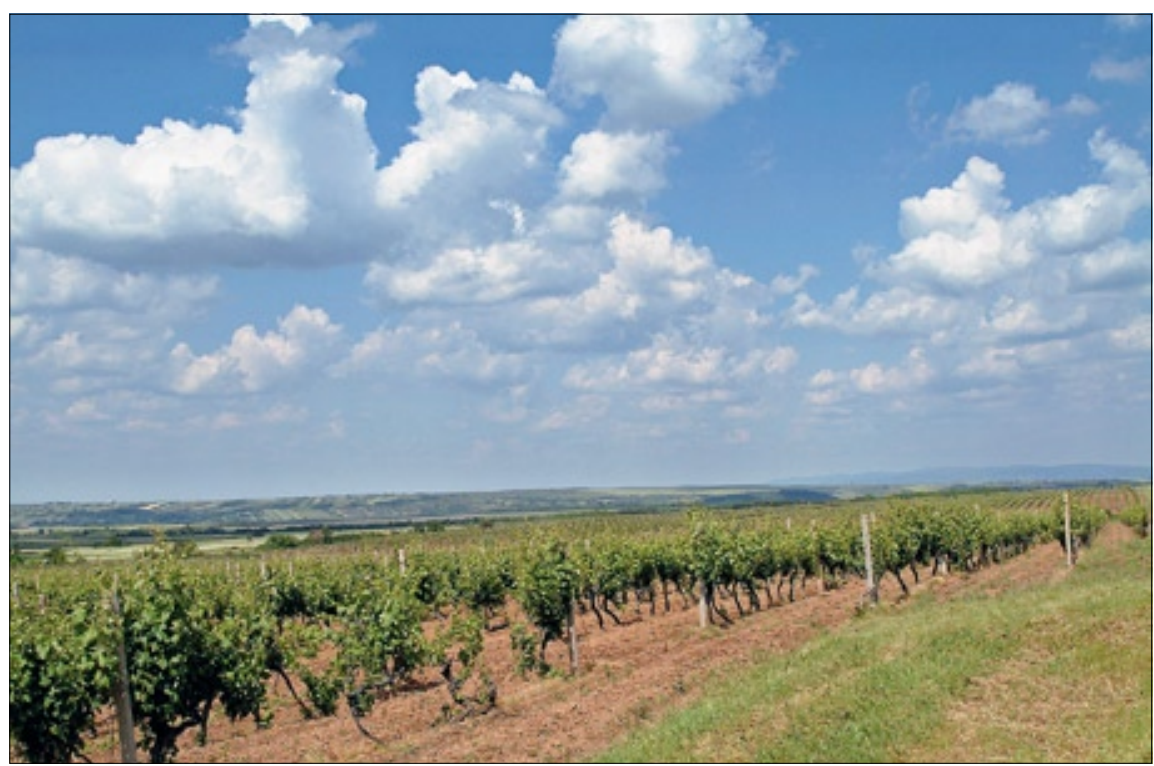

Figure 5 Vineyards around Gudurica

Figure 4 Park in the centre of village

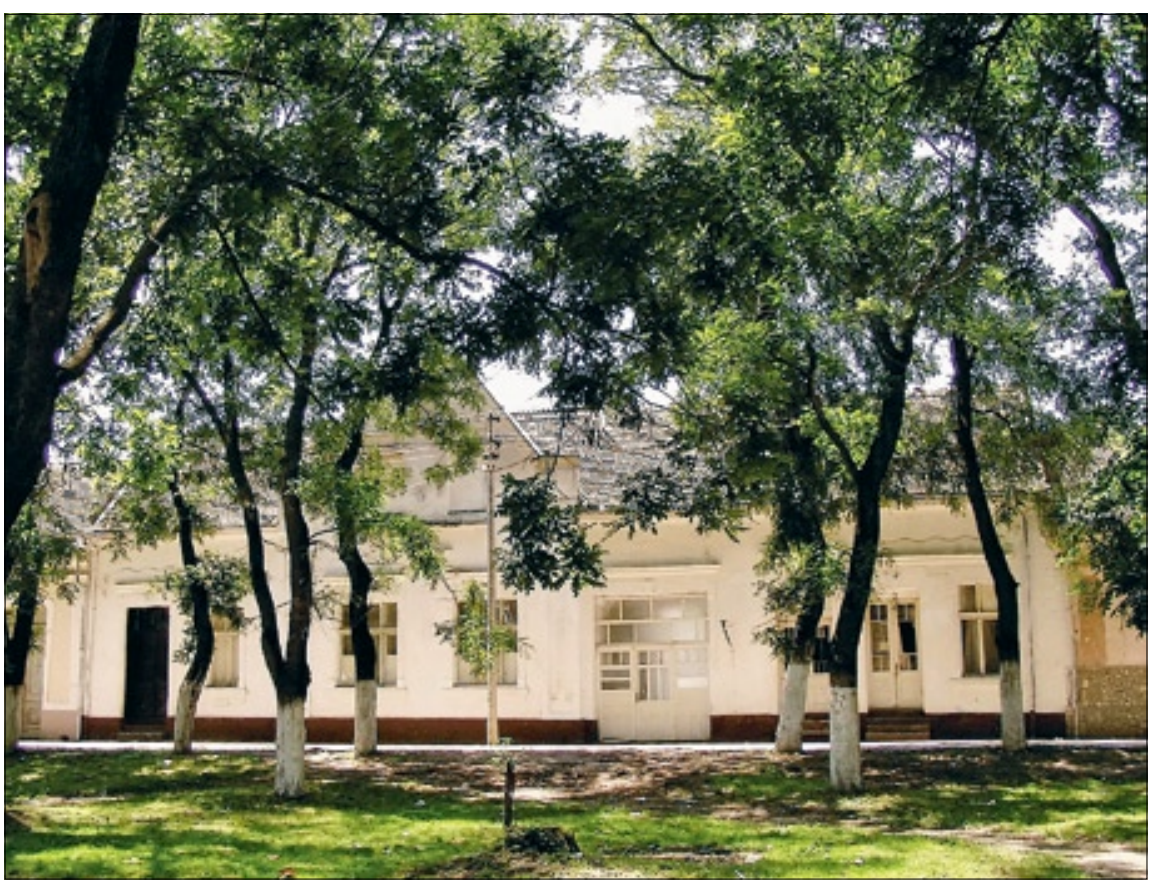

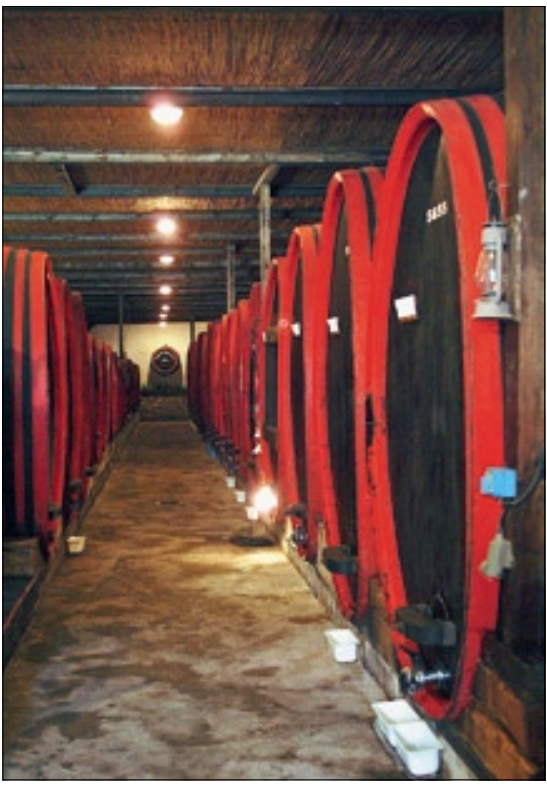

Figure 6 Wine-cellar
There are numerous historical data on that period. The data may serve as material, factual base for the homeland museum. The plans for the museum have been made and the location has been agreed upon. The opening of the museum would be purposeful, due to the fact that there are several human activities with interesting material (viticulture and wine production, history, ethnology, ethno demographic characteristics of the village through history and its problems).

In the centre of the village there are large cellars famous for wine production (Figure 5 and 6). The buildings are built in baroque style with attractive arcades. It is noticeable that the cellars are visited by the hunters and businessmen in the sector of viticulture and wine production. Lately, the cellar has been added to the tourist "wine tour". That means that there are initial motifs and categories of visitors who would encourage the building of receptive objects: restaurant with a garden, smaller museum of viticulture and wine production, degustation point, and shopping premises. Gudurica is the place with the most complex ethnic structure among the villages and well-preserved autochthonous folklore; therefore it is possible to organize performances of songs and dances of the local population in the cellar. Spacious access is suitable for building a large parking lot.

Tax from ticket sale is used for different forms of cultural-historical heritage protection, i.e. for organization and preparation of single public objects and ambient values.

\section{Population as the factor of eco-rural} tourism development

In comparison to other villages, the population of Gudurica is less involved in agriculture, but mainly employed in the facto- 


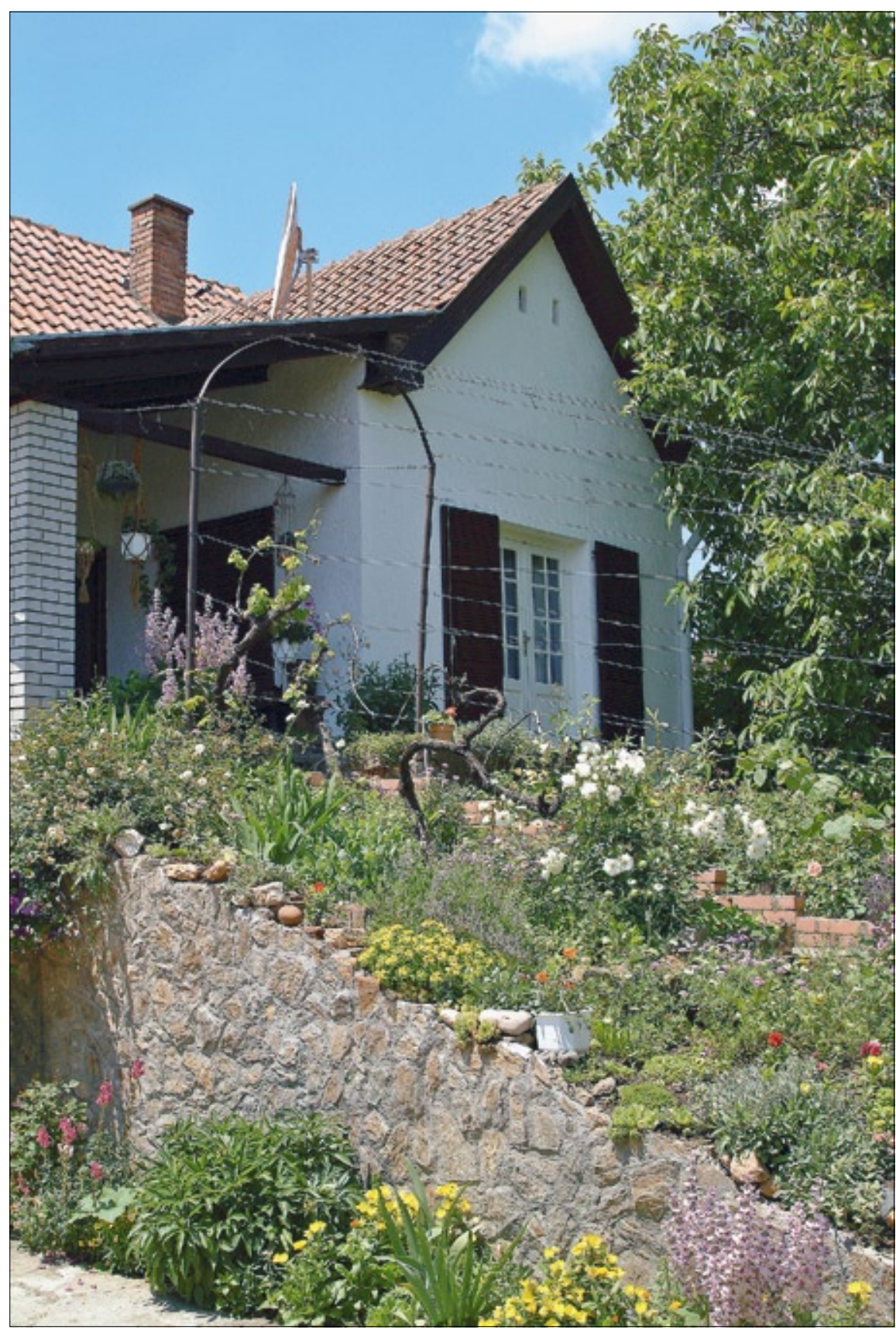

Figure 7 Potential accommodation offer

ries in Vrsac, which own certain portion of the land and vineyards in the area of Gudurica. The population, mainly the colonists from passive regions, is unaccustomed to long and heavy agricultural work. It is a fact that they never had a feeling that separation of soil working represents the most certain way of economic and social destruction. Our presumption is that they would more easily decide upon rendering tourism services, due to the fact that the agriculture is not the absolute and single way of earning money.

For this kind of eco-rural destinations it is very important that the atmosphere of conflict between those who gain and those who do not gain any advantage of tourism must not be encouraged.

At the same time it is noticeable that a large number of people have vague notions of tourism. They feel insecure and they ex- rest that their ancestors had because it had universal, civilize meaning and values.

Observing, learning and value respect make the base of tourists' visits. Therefore, everything that is valuable, attractive must be preserved. Moreover, new attractions in the spirit of eco-rural destination must be created.

For the needs of potentially interested or already interested tourists it is necessary to prepare informative, advertising material with instructions about village outline, village offer, behaviour of tourists working hours etc.

Specialized local tour guides, either from the village or from Vrsac, must be in charge of tourists. Tour guides must be previously professionally trained. Local population needs to be employed in tourist industry. Chosen individuals have to pass the test of psychophysical and social predispositions. Then there should be training in forms of seminars, workshops and other forms of education that are common for advanced personnel training. Guide's services need to be very informative.

Village as eco-rural destination must function in that way and sense. It must not be treated as greenwashing.

Contacts between tourists and local population should be spontaneous. It is necessary to cherish an exchange of ideas about all problems that may become the subject of public discussion. That means that the atmosphere of positive influence between tourists and local population needs to be created.

Creators and organizers of travel arrangements need to be proactive and they need to use their help, time and income in order to support the village development.

Approach to offer creation needs to be as creative as possible. It is necessary to constantly find new routes, new meal supplements, new places for beverages tasting, new beverages, new recreational contents, etc.

Researches showed that those tourists who have affinities towards eco-rural destinations tend to seek experiences that of fer them sense of closeness with the at tractiveness of the village and with local population.

\section{Services and eco-tourism activities that inhabitants of Gudurica will perform}

Starting from the principle of the behaviour of the population of one eco-rural destination, and taking into consideration the specific features of Gudurica, basic services and activities of the local population that is included in the tourist offer would be the following:

- boarding and daily accommodation of visitors and tourists, 
- organization of excursions to different contents of eco village and to the surrounding area,

- manufacture of agricultural and ecologically clean products (from land preparation to the preparation of food for winter),

- organization of certain sport activities - mountaineering, rock climbing horse riding school, field riding, therapeutic riding, taking part in agricultural works,

- with the help of experts from the filed of natural sciences, tourism and it would be advisable to place, in a very neighborhood of the village towards the central massif of the Vrsacke mountains, so-called eco-paths along which they can learn something new about the nature of the region (geoheritage, flora and fauna),

- production and sale of souvenirs,

- milch cows raising and sale of milk,

- production and sale of bales of hay

- wine growing, grapes and wine production, as well as production of spirits as an additional product of wine production,

- fruit growing, production of fruit brandies, production of jams,

- organization of hunting for the category of tourists that are interested in this kind of activity, whether that is game hunting, watching and photographing birds and other wild animals,

- sheep raising, production and sale of cheese, etc.

\section{Receptive basis of eco-rural tourism}

Dry, airy and light rooms with adequate furniture are necessary for the accommodation of guests. A bathroom with hot and cold water and with a toilet should be provided in every room or in every few rooms. Apart for that, a room for dining and sitting is also necessary. This room should as well portrait local architectural, pastoral ambient and other values. Rooms in a house should be dry, light and organized in such a way that they offer needed peace to guests, i.e. they should be separated from a host's private rooms (Figure 7).

Guests should be able to take part in certain household or season works. That would complete the tourist offer of village tourist economy and additionally contribute to an unforgettable stay and holiday that would differ from common contents that are offered by hotel complexes and urban environment.

Food. Although biologically healthy food is concerned here, one agricultural household that accepts tourists and offers them food services must also take into consideration different types of offers. According to need it must be prepared to offer macrobiotic food since certain tourists will ask for food suitable to their specific diet programme.

Conditions we mentioned should not be a limiting factor but offer directions for the creation of the strategy and development of future household that tends to offer tourist services. They serve the household owner when deciding in favour or against the investment in such a business.

\section{Offer of one eco-rural destination such as Gudurica}

\section{Short description village household tourism offer}

Solicitous and amiable hosts will welcome their guests with home-made brandy and wine and home-made specialties that will satisfy all European standards. Apart from those, certain recreation al programmes must be also part of their offer. These could include field work, walk down the valley sides of Markovacki brook, mountain trekking - either along the piedmont area or central mountain massif, either through forest complex or through meadow-pasture terrain. Tourist will enjoy the picking of mushrooms, medicinal herbs or getting to know some of the domestic animals. If a host wants those days spent in one such house to stay memorable he also offers certain home-made products for sale (food, clothes or shoes made of natural materials), brandy and wine.

Offer can include walking, panoramic flights, bird watching in forest-mountainous part of the area, mountaineering, balloon flight, different sports, contact with numerous domestic and wild animals (dog, cat, duck, goose, horse donkey, goat, sheep, cow, pheasant, pigeon, roe deer).

On the base of the experience in contact with guests, hosts will be in possibility to offer home specialties to the choosiest guests. Food is fresh and healthy, and must distinguish itself with specialties typical for Banat cuisine and cuisine that is preserved from areas that this colonized population originates from, but only if it is prepared in authentic way. Food and drink must be nicely arranged on the table during meals. The cleanliness of kitchen utensils must be on a very high level.

Wooded hills of pleasant mountain surrounding are ideal for hunting. Tourists can enjoy the untouched nature and fresh air while picking the mushrooms or walking down the marked and well-arranged mountain path that makes one part of socalled Vrsac transversal. Paths that border the transversal, especially in the north part of the area where they cover abrasive terraces are suitable for jogging, mountain bike riding or horse riding. It is necessary to emphasize that host's behaviour also influences the quality of one tourist product. What is necessary is offer that is typical for one agricultur- al household. It is of great importance that host likes socializing with the guest, that he is direct in communication and that he can make atmosphere more relaxing.

Certain houses that do not offer overnight stays but can accept guests are suitable for one or half day stays or can offer any shorter services.

In Croatia, Slovenia and other countries that are spatially or ethno-demographically close to us there are experiences and customs that function quite well. Host has his own secret of brandy making (so-called "double distilling") and this is where certain high quality drinks such as "Antina viljemovka", "Kajina Šljivovica" and "Kruškova rakija" come from. Certain similar attempts are noticed in Gudurica. Brandy and wine should distinguish themselves with original packagings that keep up with world trends. It is good that this category of hosts that create tourist offer take part in fairs in country and abroad. Each award and medal will just contribute to the increase of demand.

When rural tourism is concerned, and as seen from the experience, there is often one problem present that needs to be taken care of. Namely, it is known that at the very beginning people decided to take up projects of rural tourism out of pure love. After this project has experienced success people usually think of it as a source of easy earning. However, experts in this form of tourism emphasize: guests cannot be just rented a house and then disappear. A large number of guests wants communication with their hosts. Contact, cordiality and communication are parts of a very product. That is why it is necessary to educationally act upon the local population and constantly remind them of the need for the respect between a guest and a renter.

\section{Tourism offer of public rural objects}

In order for rural objects to be even more attractive, it is necessary to take care of them with lots of affection and love without forgetting tradition and past. After the central square is nicely arranged it is necessary to light this area during night, especially old buildings around it (cellar, church and similar). Thus reconstructed half-urban and half-rural ambient would gain one more expressed esthetical component.

When the usage of so-called rural houses, i.e. old buildings renovated in recognizable autochthonous style is concerned it is necessary to mention that they must represent one well-arranged, integral part of Gudurica offer where Gudurica is experienced as one eco-rural destination. In contrast to the most of other settlements in Vojvodina, the basic building material here was stone from Vrsacke mountains. This should also be the case in the 


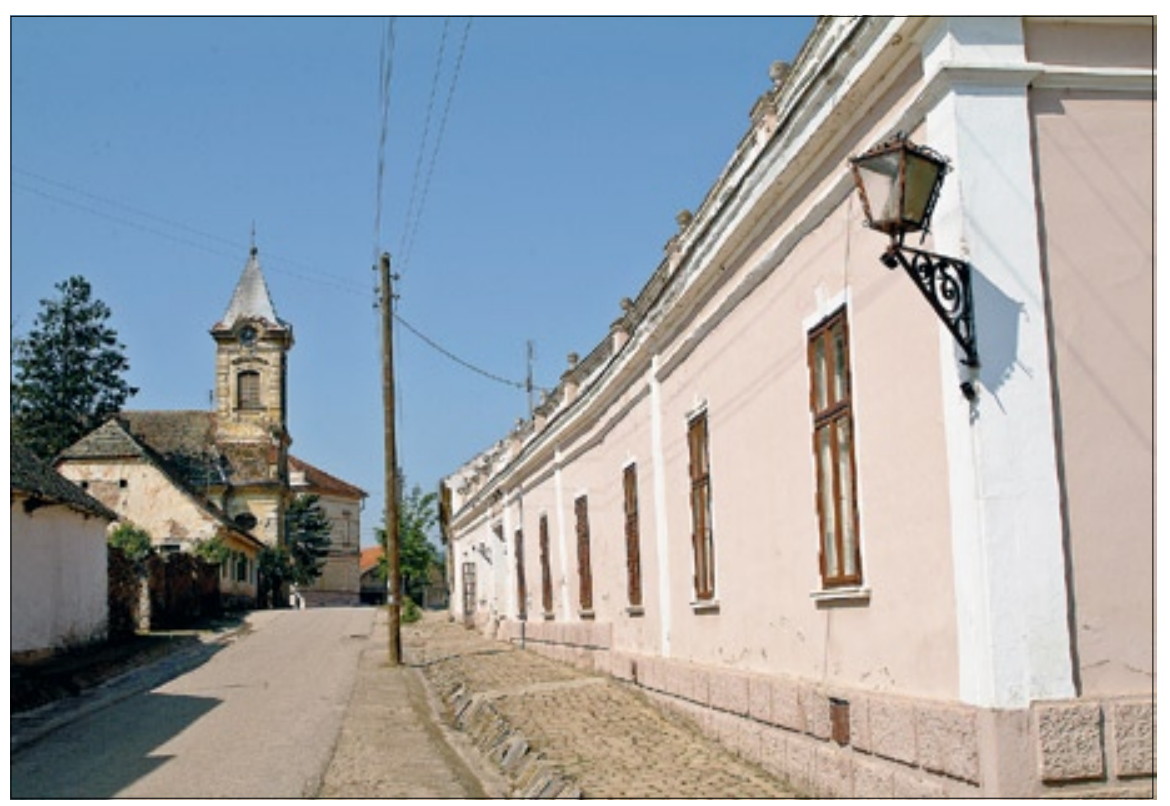

Figure 9 Centre of village with Catholic church

future, with economical and appropriate building of both residential and accompanying buildings and village canals. Certain parts of those objects (entrance gates, floors, supporting beams, certain stairs, yard parts, barns, tables, chairs etc.) were previously made of wood (there are plenty of it on Vrsacke mountains), and that tradition should also be preserved.

Every type of public object outside an agricultural household has its own specific purpose and contents that will offer the tourists. Cellar, where tourist will learn something about its structure and purpose, will also be the place where tourists could get information and chat about grapes, wine, good and bad grape years, conditions of climate elements and their influence upon works, about wine and table grape sorts. Wine tasting can also be organized here. Hosts could reveal the secrets of good and bad wine, traditional technology and new technologies.

Culture centre is object located in the centre of the village facing the park. This object should keep its primal function since the building with its ascetic building structure and narrowly oriented function speaks about one period in our history when whole cultural life of village was oriented only towards culture centers (Figure 8 and 9). The name of this building "Moše Pijade" should be kept, because the life and aspiration of this painter and his revolutionizing determination symbolize the time when these kinds of objects were on the peak of their existence. Culture centre has a hall with 250 seating places that are mainly used for cinema purposes. The hall has a stage that is apart for other purposes used every first weekend in September when Ethnofestival is held. Festival has a role model in exceptionally well-organized manifestation "Food and music" that is held every June in Novi Sad.
Culture centre has a library, restaurant and bar. Yard area is very spacious and is used as an open air stage for the needs does not require large investment in its re-

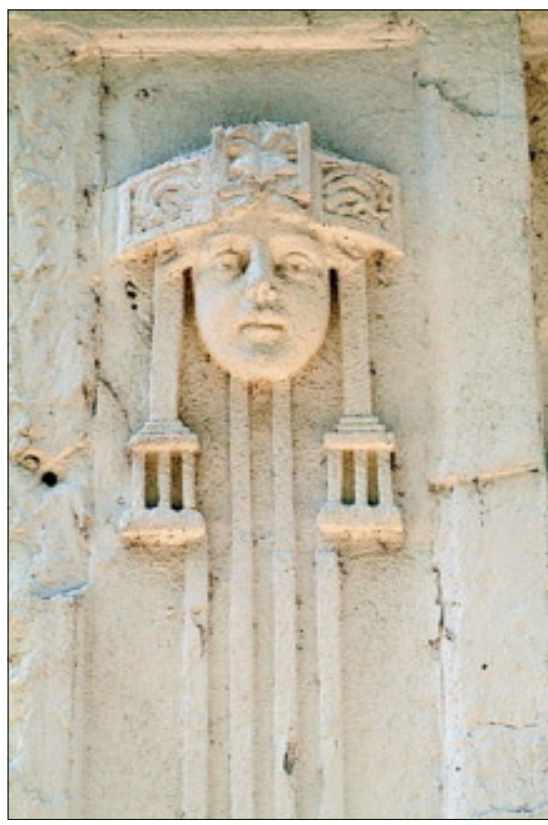

Figure 8 Secession detail on one of the facades

construction. Its present purpose should be preserved. However, it could also be used for performances of local folklore associations from Gudurica and surrounding villages, especially when those need to be presented to tourists.

Opposite the Culture centre, at the other side of the park, there is pensioners' centre with an interesting name "Old citizens' centre 'Čokot' - Gudurica”. The building in its front part facing the street has a restaurant, whereas at the back part there are the premises of Chess club "Čokot". Adjoining it there is one building that is almost destroyed. On its place a new building for Tourist organization, Museum and $\mathrm{Bu}$ of the mentioned festival. Culture centre reau for wine sale coordination will be built. There is plan to build court for "boćanje" in the yard. This sport is typical for Mediterranean. However, since there are many people in the village who came from Dalmatia or whose ancestors are from Dalmatia there are many admirers of this interesting game. Part of autochthonous population also gladly plays this game. This fact should be used to include this sport into eco-rural offer of the village.

Hunting house is nice building with hunting restaurant, bar, room for keeping trophies. It is located in the central part of the village in street Gradnikova 14. Hunting organization in its beautiful objects will organize hunting, but also will be the centre of hunting stories, lunches and dinners, and meetings of hunters' families. It is considered one of the most attractive in Vrsac municipality. All these need to be used as part of the attraction, although they are not completely in the spirit of one eco-rural destination.

Old citizens' organization is very active and it is the organizer of many sporting-recreational activities that can become part of tourist offer.

Catholic-protestant (German) church is certainly one of the most beautiful objects in the village. It is partially renovated. However, that is not enough and if the roof is not to be fixed as soon as possible it will result in destruction of valuable and so far well-preserved inner church part with church relics and pipe organ, which is still in quite a good condition. Due to the lack of believers there is no special interest for it among the local population. However, this kind of object with cultural-historical importance needs to be renovated by means of foreign (German) associations and used as place for chamber and church music concerts. Cultural happenings can broaden depending on the interest of tourists.

\section{Benefits of eco-rural tourism}

Village Gudurica with the central massif and slopes of the Vrsacke mountains, which with its significant part belongs to the district of this village, has a lot of advantages for the development of eco-rural tourism (Figure 10, 11 and 12). They represent the unique union of culture, history, natural beauties, ethno demographic values, autochthonous gastronomical products.

Viticulture and wine production have very long tradition and need to be revitalized in order to fulfill high standards.

The advantages of the development of eco-rural tourism in this area are: revitalization of interesting and once very demographically and economically vital village, preservation of the rural area population, employing a large number of people, preparing village population for independent 
work, recovery of viticulture and wine production, recovery of cattle raising, opening of one small horse farm and one association that would educate local population and interest the guests, recovery of old craft trades, recovery of authentic customs, preservation of social and culture specificities, stimulation of primal farm products and procession of agricultural products.

The programme of development of rural tourism would contain the following forms of tourism: 1) tourism in village family buildings, 2) wine routes, 3) cultural tourism, 4) sporting recreational usage of marked walking, cycling, trekking, riding paths; horse hire, 5) trekking along the marked paths, with the possibility of choice between paths of different lengths and difficulties; walking in continuity or walking from one to another natural or culturalhistorical attraction, 6) hunting tourism, 7) health tourism and 8) eco-tourism.

\section{Planning and management of rural tourism development and education problems}

The general aim of planning and management of rural tourism development would be the creation of the balance between demand and offer, i.e. overall capacities (spatial and others) with an aim to minimalize conflicts and to fully utilize natural bases for tourism development, without degrading the environment.

The types of rural tourism are determined according to the presence of suitable resources for the development of tourism and tradition of rural tourism development. In that sense, Gudurica belongs to the second type that is marked as rural area with important resources, but without enough tradition in tourism development.

One of important preconditions for successful planning and management of

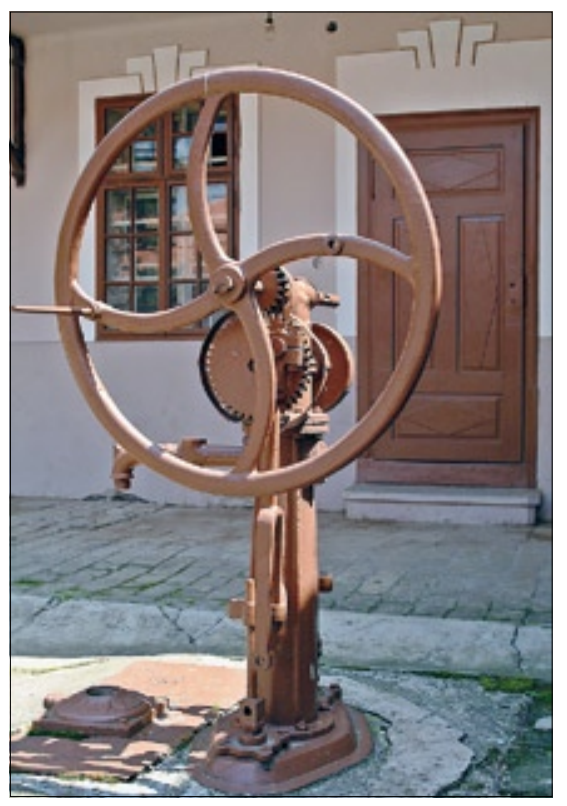

Figure 11 Old well in wine-house

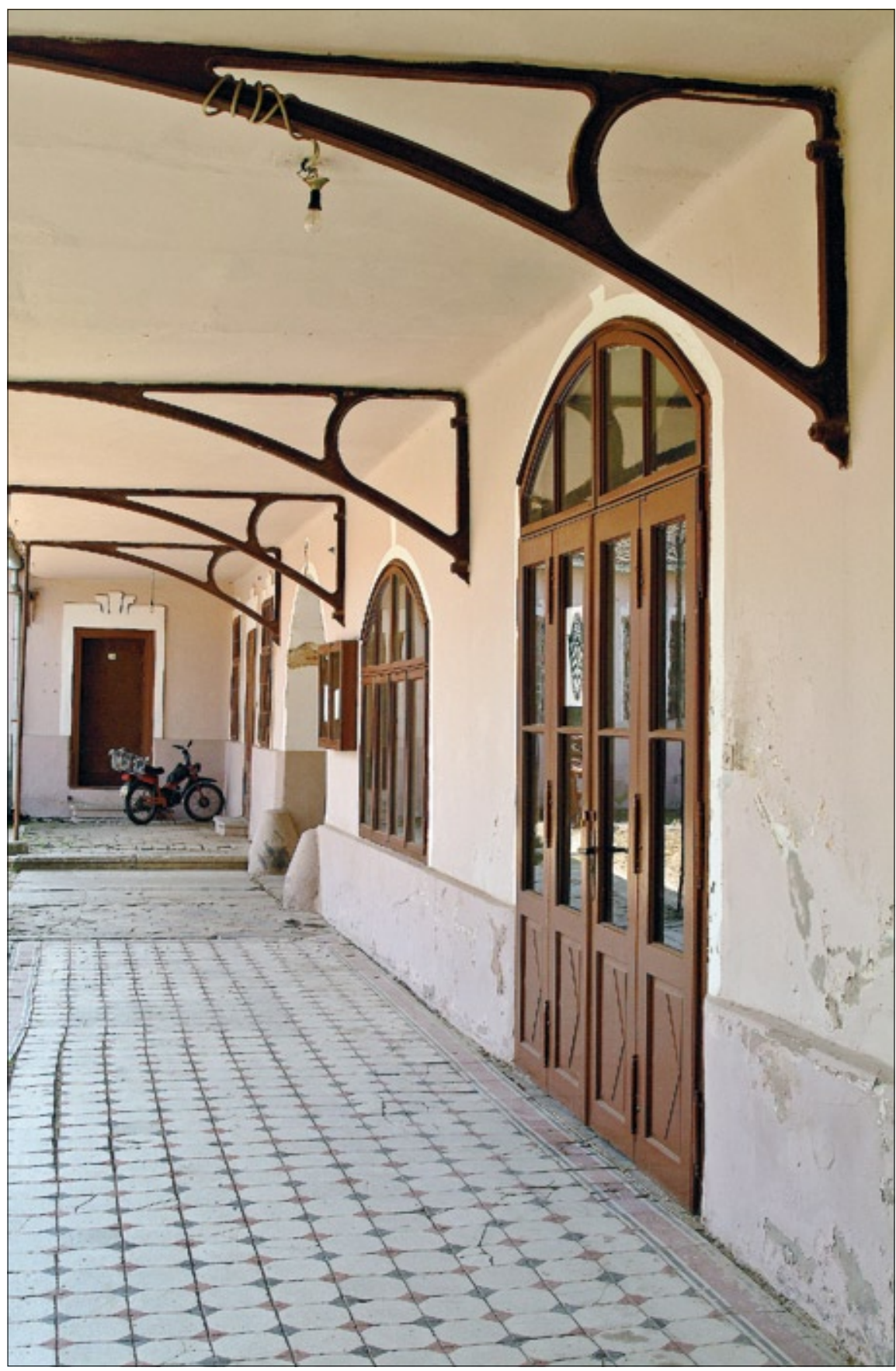

Figure 10 Traditional architecture

rural tourism sustainable development is active involvement of local community, i.e. population into that process. Every usage of resources for the needs of tourism development, without the approval of local community, can be marked as abuse by local population and represents dissimulating factor of rural tourism development.

It is necessary to educate visitors as well how to use resources in rural areas. One of the most common ways of this kind of influence is proclamation of official rules of behaviour so that visitors, i.e. tourists, by adapting their behaviour could bear a part of responsibility in resources' protection.

It is necessary to educate key participants who take part in fulfilling the needs of tourists. Education should be directed towards: the needs of tourists, informing population about managing skills, account- ing, providing conditions for the recreation of guests, the safety of tourists, hygiene for tourists, expanding their knowledge of natural, cultural and other characteristics of their area, gradation of their values etc.

It is necessary to educate the entire population - so that they would participate in the realization of the joint project of the development of rural tourism; employees in local tourist information centers, local travel guides and animators - with an aim to gain wider knowledge about the characteristics of the region, especially tourism resources, ways advertising tourist products, recreational techniques, etc.

One of the important and inevitable activities in village is organization and maintenance of the whole area, village and surrounding region. 
Education of population can be organized in forms of seminars. One of those could be about "Quality of guests' acceptance in rural tourism'. Seminar should be of universal character and be directed towards the arrangement of households, village and all the accompanying activities in the function of tourism.

Italian experiences about eco-rural tourism show the following (Luiza Rosina Poeta from Este): "everything begins with a man who wants to work in tourism. Small steps make a lot; one room is enough for start. Will is important in everything, as well as knowledge that can be gained during visits to other tourist regions and while taking part in seminars. Globalization is not a competition for rural tourism because tourism has its own path and its own escort that consists of the development of small, tiny economic subjects that are mutually dependent".

Marketing is very important and money must be invested in it because it is marketing that brings guests. Nowadays it is well known that potential tourists try to find on the Internet destination that is different from the others and that suits them.

\section{Creation of eco-rural destination}

Eco-rural destination appears when local community has certain benefits of tourism. That must be understood as a possibility for development that is offered to them.

The thing that is important for eco-rural tourism is the fact that everything begins with materially and financially modest, poor environment. That is why the basic condition for success is realization of strong investments.

A planned exploitation of rural tourism is one of the most usable ways of village recovery. That is necessary because village economically impoverishes, communal infrastructure is bad while the development of commercial agriculture is not possible due to reduced properties.

Steps in building projects, i.e. in the arrangement of the village and surrounding area would consist of the following:

- arrangement of the park in the centre of the village - hire experts from the field of horticulture who are to make park plan and to conduct its reconstruction, rebuilding and reconstruction. It is also necessary to inform population about that by means of public bards, printing material, inform them about goals, importance and duration of works, as well as about other relevant information that experts from the field of horticulture and recreation consider important;

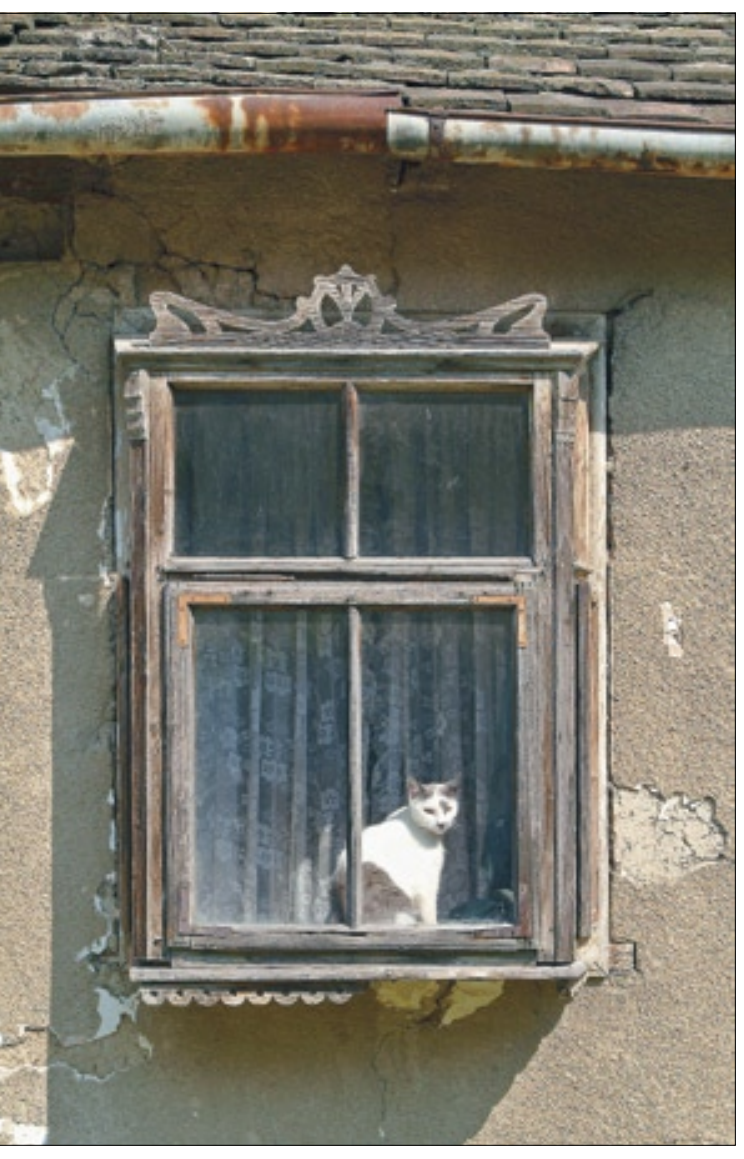

village, which would emphasize both positive and negative examples. Internet presentation is compulsory. The creators of marketing part of work need to examine examples from neighboring countries. Compact discs in forms of postcards, video cassettes and DVDs also need to be made.

Together with the restoration of representative buildings, arrangement of ambience in the centre of the village and with the realization of basic infrastructure, as well as with making first houses ready for guests' occupancy, it is necessary for one travel agency to accept organized sale of rural houses and agro-tourist households. When certain success is achieved it is necessary that the agency accepts the obligation of publishing catalogues that would contain representative objects and events (manifestations).

These steps would give people who invested money into the restoration of houses and agencies the things they missed, and that is what organized market is.

Figure 12 Traditional window („kibicfenster")

- reconstruction of public water supply network;

- rebuilding of access roads and roads within the very village, as well as of pavements and canals;

- arrangement of parking lots using the system of hollow concrete bricks or large rocks so that grass planted in the gaps would esthetically mark green, attractive oasis;

- cleaning of Markovacki brook and the surrounding area (bed, valley bottom, valley sides) from existing waste material, and at the same time take measures to prevent causes of mechanical, chemical, and organogenetic pollution. What is more, it is necessary to remove all weeds, especially those bigger ones and those that cause health problems and limit the recreation;

- building of stables for renting riding horses. Although this activity does not have tradition in the village, it is necessary to find ways to engage agricultural households that have positive experiences in horse raising and that could easily adapt to raising and breeding of riding horses;

- renting and arrangement of areas for sheep, horse and other animals pasture.

\section{Informative and advertising activity}

In the spirit of eco-rural destination it is advisable to print four-coloured brochures, catalogues depicting life in the

\section{References}

Bajić, M. 1984. Opština Nova Crnja, Prirodno-metematički fakultet, Institut za geografiju, Novi Sad. pp. 1-197.

Bugarski, D., Tomić, P. 1988. Hidrografske karakteristike Vršačkih planina, Matica srpska, Novi Sad. pp 1-41.

Bukurov, B. 1955. Vršačke planine, Prilog geografiji Vojvodine, Matica srpska, Novi Sad. pp. 1-161.

Bukurov, B. 1970. Naselja u južnom Banatu, Zbornik Matice srpske za prirodne nauke 39, 5-68.

Bukurov, B. 1982. Sintetička razmatranja geomorfoloških problema na teritoriji Vojvodine, VANU, Novo Sad.

Grupa autora 1979. Vršac - Prostorni plan opštine, 2 knjiga, Zavod za uranizam i komunalno-stambena pitanja SAP Vojvodine, Novi Sad.

Grupa autora 1978. Generalni urbanistički plan Vršca, Zavod za urbanizam, Novi Sad.

Grupa autora 1986. Zaključci i predlozi 5. kongresa vinogradarstva i vinarsta. broj 10, Institut za spoljnu trgovinu, Beograd.

Plavša, J., Romelić, J. 1992. Mogućnosti razvoja turizma Vršačkih planina, Zbornik radova instituta za geografijju 22, 75-81.

Romelić, J., Tomić, P. 1991. Geografski problemi pograničnih naselja Vršačkih planina, Zbornik sa naučnog skupa u Negotinu, Geografski fakultet, Beograd. 